\title{
VARIASI KOMPOSISI BAHAN BAKU TERHADAP MUTU ORGANOLEPTIK MIE TEPUNG PISANG
}

\section{INGREDIENTS COMPOSITION VARIATION AGAINST ORGANOLEPTIC QUALITY OF BANANA FLOUR NOODLES}

\author{
Dewi Siti Rahayu ${ }^{1}$, Siska Apriyani², Ahmad Zueni ${ }^{3}$ \\ 1) Program Studi Teknologi Pangan Fakultas Pertanian UNIVED \\ 2) Program Studi Teknologi Pertanian Fakultas Pertanian UNIVED \\ ${ }^{3)}$ Program Studi Agribisnis Fakultas Pertanian UNIVED
}

\begin{abstract}
ABSTRAK
Mie tepung pisang adalah produk olahan dari pisang panjang, dimana proses pengolahan cukup mudah. Mie tepung pisang dalam pengolahannya melalui beberapa tahapan yaitu proses penyortiran, pencucian, pencampuran, pencetakan dan pemasakan sampai mendidih. Proses ini merupakan salah satu faktor yang dapat menentukan kualitas pisang mie tepung, salah satunya dari sifat organoleptik mie tepung pisang. Tujuan dari penelitian ini adalah untuk mengetahui pengaruh penambahan tepung pisang terhadap sifat organoleptik mie tepung pisang. Penelitian dilakukan dengan tiga perlakuan, yaitu proses pengolahan yang pertama dilakukan dengan penambahan 100 gram tepung pisang, pengolahan kedua dilakukan dengan menambahkan 200 gram tepung pisang dan pengolahan yang ketiga dilakukan dengan penambahan 300 gram tepung pisang. Analisis dilakukan adalah analisis organoleptik. Kesimpulan dari penelitian ini menyatakan bahwa dalam hal parameter warna, aroma, dan tekstur mie tepung pisang yang paling disukai adalah mie tepung pisang dengan penambahan 200 gram tepung pisang.
\end{abstract}

Kata kunci : Mie, Tepung pisang, Sifat organoleptik

\section{ABSTRACT}

Banana flour noodles are processed products of banana length, where in the processing process is fairly easy. Banana flour noodles in the treatment process through several stages of the process of sorting, washing, mixing, molding until boiling . Of these processes are one of the processes that determine the quality of banana flour noodles can be determined from the organoleptic properties of banana flour noodles. The purpose of this study was to determine the effect of the addition of banana flour on the organoleptic quality of banana flour noodles. The study was conducted with three treatments, namely the first treatment process carried out by the addition of 100 grams of banana flour, the second treatment is done by adding 200 grams of banana flour and treatments to three performed with the addition of 300 grams of banana flour. Analysis is conducted organoleptic analysis. The conclusion of this study found that in terms of the parameters of color, flavor, and texture of banana flour noodles that is most favored by the addition of 200 grams of banana flour.

Keywords : Noodles, Banana flour, Organoleptic properties 


\section{PENDAHULUAN}

Pisang ( Musa paradisiaca L) adalah salah satu buah yang digemari oleh sebagian besar penduduk dunia. rasanya enak, kandungan gizinya tinggi, mudah didapat, dan harganya relatif murah (Cynthya, 2006). Indonesia adalah bagian dari pusat asal pisang ( Musa paradisiaca L), sekaligus pusat pembudidayaannya. Oleh karena itu, tanaman pisang ( Musa paradisiaca L) dijadikan salah satu bahan makanan ringan oleh masyarakat Indonesia. pisang bisa tumbuh didataran rendah dan dataran tinggi, sehingga tumbuhan ini sangat mudah dikembangkan. Pisang (Musa paradisiaca L) merupakan salah satu golongan buah-buahan. Menurut Kartasapoetra (1998), golongan buahbuahan jenis pisang ini sudah sepatutnya untuk dikembangkan. Selain dapat digunakan sebagai makanan masyarakat, pisang juga mempunyai prospek sebagai bahan dasar industri. Maka tidak terlalu berlebihan bila tanaman ini jika dikembangkan akan bisa menjadi tanaman komersial dibidang pertanian.

Jenis pisang banyak sekali antara lain pisang kepok, pisang ambon, pisang raja, pisang kapas, pisang susu dan masih banyak jenis pisang lainnya tetapi jenis pisang yang biasa digunakan oleh para pedagang pisang goreng, molen goreng dan para pengusaha makanan yang menggunakan buah pisang sebagai bahan baku pada umumnya adalah pisang raja, pisang kepok, dan pisang ambon, dimana buah pisang setelah diambil buahnya, kulitnya dibuang begitu saja di tempat pembuangan sampah dan belum dimanfaatkan untuk dicoba sebagai bahan dasar makanan yang menguntungkan secara ekonomi.

Pisang merupakan salah satu tanaman buah unggulan yang penmanfaatan pisang pada saat ini masih terbatas dalam bentuk segar untuk pengolahan dodol, keripik dan jajanan lainnya. Salah satu teknologi lainnya untuk dapat meningkatkan nilai ekonomis pisang adalah dapat dikeringkan dan diolah menjadi tepung. Tepung pisang adalah hasil penggilingan buah pisang mentah yang sudah dikeringkan, hampir semua jenis pisang mentah dapat dikeringkan dan diolah menjadi tepung. Tepung pisang ini merupakan alternatif produk setengah jadi yang sangat dianjurkan karena lebih tahan lama bila disimpan, mudah untuk dicampur dan lebih instan dalam pemakaiannya. Pembuatan tepung yang tidak terlalu mahal pisang ini mudah dilakukan oleh para petani, dan dengan biaya tidak terlalu mahal. Ada 
beberapa manfaat yang dapat diperoleh bila petani mengolah tepung pisang antara lain umur simpan lebih lama, memudahkan dalam pengemasan dan transportasi penjualan, dapat dijadikan berbagai olahan pangan dan menciptakan peluang usaha di pedesaan. Pisang merupakan tumbuhan asli Asia Tenggara, yaitu berasal dari Semenanjung Malaysia dan Filipina. Tetapi ada juga yang menyebutkan bahwa pisang berasal dari Brasil dan India. Dari sini kemudian menyebar hingga ke daerah Pasifik (Cinthya, 2006).

Dari hasil berbagai penelitian diketahui bahwa buah pisang mengandung gizi yang sangat baik. Di dalam buahnya terdapat energi yang cukup tinggi dibandingkan buah-buahan yang lain. Pisang kaya mineral seperti kalium, magnesium, fosfor, besi dan kalsium. Berdasarkan kandungan energi dalam buah pisang maka pisang direkomendasikan oleh para ahli herbal untuk mengobati berbagai jenis penyakit, seperti pendarahan rahim, sariawan usus, ambeien, cacar air, telinga dan tenggorokan bengkak, disentri, amandel, kanker perut, sakit kuning, pendarahan usus besar, diare, dan lain-lain. Pisang juga dapat mengobati tekanan darah tinggi, karena pisang mengandung potassium yang tinggi yang berguna bagi orang yang harus melakukan diet rendah garam.

Mie tepung pisang sudah sejak lama dikenal masyarakat sebagai jajanan yang cukup mengenyangkan. Selain untuk makanan selingan atau kudapan, sering menggantikan menu sarapan pagi dan bekal sekolah anak. Saat ini mie tepung pisang termasuk salah satu kue yang diminati oleh anak-anak hingga orang tua (Sufi, 2009). Panganan ini cukup mengenyangkan karena ia mengandung karbohidrat dari tepung dan sumber energi dari manisnya gula tepung (Almatsier, 2009).

Bahan utama pembuatan mie adalah tepung terigu yang mana selama ini mie yang biasa dikonsumsi hanya mengandung zat gizi makro saja yaitu karbohidrat, protein dan lemak, dan sedikit atau bahkan tidak mengandung zat gizi lainnya seperti vitamin dan mineral. Sehingga diharapkan dengan penambahan tepung pisang dapat memperbaiki kandungan gizi mie terutama kandungan vitamin dan mineralnya karena pisang kaya akan kandungan vitamin dan mineral dan juga dapat mengurangi ketergantungan terhadap tepung terigu. Berdasarkan latar belakang yang telah diuraikan di atas maka perlu dilakukan penelitian untuk 
mengetahui mutu organoleptik mie tepung pisang.

\section{METODE PENELITIAN}

\section{Bahan dan Alat}

Adapun bahan dasar dan bahan pendukung yang digunakan untuk pembuatan mie tepung pisang adalah buah pisang panjang yang mentah diolah menjadi yang menjadi tepung pisang, tapioka, telur, penyedap rasa,garam dan air. Alat-alat yang digunakan dalam proses pengolahan atau pembuatan mie tepung pisang adalah pisau, penyaringan, mesin penggiling, baskom, kompor, ampia, plastik pembungkus, timbangan, dandang dan sendok.

\section{Metode}

Penelitian dilakukan tiga tahap, yaitu tahap pengolahan tepung pisang, tahap pembuatan mie tepung pisang, dan tahap analisis. Proses pembuatan tepung pisang antara lain pengupasan kulit pisang, pemotongan daging buah pisang, perendaman buah pisang dalam larutan natrium tiosulfat selama \pm 15 menit, penirisan, pengeringan selama dua hari, penggilingan, dan pengayakan.

Proses pembuatan mie tepung pisang meliputi pencampuran bahan dasar yaitu pisang panjang yang telah diolah menjadi tepung pisang (100 gram, 200 gram, 300 gram) dengan tepung terigu 700 gram, 100 gram tapioka, dan 2 butir telur dengan bumbu yakni berupa garam, penyedap rasa, serta $500 \mathrm{ml}$ air. Tahap Pelempengan/pemipihan, Pencetakan perebusan kurang lebih 30 menit, pendinginan. Analisis yang digunakan adalah analisis tingkat kesukaan konsumen dengan jumlah panelis 80 orang dengan parameter penilaian warna, rasa, dan tekstur dengan skala penilaian 1 $=$ suka sekali, $2=$ suka, $3=$ agak suka, 4 $=$ tidak suka, $5=$ sangat tidak suka

\section{HASIL DAN PEMBAHASAN}

\section{Warna}

Dalam menentukan mutu pangan pada umumnya sangat bergantung pada beberapa faktor diantaranya warna, rasa dan tekstur. Sebelum faktor-faktor lain, secara visual faktor warna tampil terlebih dahulu dan kadang-kadang sangat menentukan. Daya tarik suatu jenis makanan lebih sering dipengaruhi oleh kenampakan warna sebagai salah satu sifat. Kenampakan mempunyai peran penting dalam menentuka mutu pangan. Selain sebagai faktor yang ikut menentukan mutu, warna juga dapat digunakan sebagai indikator kesegaran atau kematangan. Baik tidaknya cara pencampuran atau pengolahan dapat 
ditandai dengan adanya warna yang seragam dan merata (Soekarto, 1985).

Tabel 1. Nilai Rata-rata Tingkat Kesukaan Konsumen terhadap Parameter Mutu Warna Mie Tepung Pisang

\begin{tabular}{lcc}
\hline No & Komposisi Bahan Baku & Nilai Rata-rata \\
\hline 1 & 100 gram & 2,66 \\
2 & 200 gram & 2,50 \\
3 & 300 gram & 3,91
\end{tabular}

Keterangan skala penilaian $1=$ Suka sekali $: 2=$ Suka $: 3=$ Agak suka $: 4=$ Tidak suka $: 5=$ Sangat tidak suka

Berdasarkan uji organoleptik mutu warna diatas, mie tepung pisang yang paling disukai oleh panelis adalah mie tepung pisang dengan penambahan 200 gram tepung pisang, karena panelis lebih menyukai warna yang kuning. Sedangkan mie tepung pisang dengan
100 dan 300 gram berwarna coklat kekuningan hal ini disebabkan oleh kadar air yang lebih banyak atau kurang pada bahan pembuatan mie tepung pisang. Adapun hasil analisa uji statistik berdasarkan table anova dapat dilihat pada tabel 2 berikut ini:

Tabel 2. Anova Parameter Mutu Warna Mie Tepung Pisang

\begin{tabular}{llllll}
\hline SV & Db & JK & MS & F Hitung & F Tabel \\
\hline Panelis & 79 & 101,15 & 1,28 & 0,29 & 1,36 \\
Perlakuan & 2 & 95,57 & 47,78 & 11,08 & 3,06 \\
Error & 158 & 681,15 & 4,31 & - & - \\
Total & 239 & 877.87 & - & - & -
\end{tabular}

F Hitung $>$ Tabel Berberda Nyata

F Hitung $<$ Tabel Tidak Berbeda Nyata

Berdasarkan uji sensoris yang hasil yang berbeda nyata pada parameter dilakukan parameter rasa, berarti tidak mutu warna.

berbeda nyata. Hal ini menyatakan bahwa penilaian antar panelis terhadap

2. Rasa

ketiga sampel adalah sama. Hal ini Rasa adalah indra pengecap, dalam menunjukan bahwa panelis menilai parameter warna. Hal ini menyatakan kepekaan rasa maka rasa manis dapat dengan mudah dirasakan pada ujung 
lidah, rasa asin dapat dirasakan pada ujung dan pinggir lidah, rasa asam pada pinggir lidah, rasa pahit pada bagian belakang lidah. Rasa biasanya ditentukan oleh salah satu zat dominan dan bersifat professional dalam susunan zat-zat yang memberikan rasa. Cita rasa juga sangat mempengaruhi derajat penerimaan konsumen (Winarno, 1995).

Tabel 3. Nilai rata-rata parameter mutu rasa mie tepung pisang

\begin{tabular}{lcc}
\hline No & Komposisi Bahan Baku & Nilai Rata-rata \\
\hline 1 & 100 gram & 2,66 \\
2 & 200 gram & 2,48 \\
3 & 300 gram & 4,93 \\
\hline
\end{tabular}

Keterangan skala penilaian $1=$ Suka sekali $: 2=$ Suka $: 3=$ Agak suka $: 4=$ Tidak suka $: 5=$ Sangat tidak suka

Berdasarkan uji organoleptik mutu rasa di atas, mie tepung pisang yang paling disukai oleh panelis adalah mie tepung pisang dengan penambahan 200 gram tepung pisang, karena panelis lebih menyukai rasanya. Sedangkan mie tepung pisang dengan 100 gram dan 300 gram rasanya tidak begitu manis. Adapun hasil analisa uji statistik berdasarkan table anova dapat dilihat pada tabel 4 berikut ini:

Tabel 4. Anova Parameter Mutu Rasa Mie Tepung Pisang

\begin{tabular}{llllll}
\hline SV & Db & JK & MS & F Hitung & F Tabel \\
\hline Panelis & 79 & 103 & 1,3 & 0,32 & 1,36 \\
Perlakuan & 2 & 100,43 & 50,21 & 12,55 & 3,06 \\
Error & 158 & 633,57 & 4 & - & - \\
Total & 239 & 260,43 & - & - & - \\
\hline
\end{tabular}

Berdasarkan uji sensoris yang dilakukan dengan parameter rasa hasilnya berarti berbeda nyata hal ini menyatakan bahwa penilaian panelis terhadap ketiga sampel parameter rasa., berbeda nyata karena dari penilaian panelis dari ketiga sampel rasa jauh berbeda, sedangka pada masing-masing perlakuan menunjukan hasil yang berbeda nyata.

\section{Tekstur}

Tekstur adalah kenampakan bentuk, gambaran, pola. Atau mutu suatu produk 
bisa juga disebut dari indera peraba, dengan jari dan konsistensi merupakan merupakan sensasi tekanan yang dapat tebal, tipis dan halus (Soekarto, 1985).

diamati dengan mulut atau perabaan

Tabel 5. Anova parameter mutu tekstur

\begin{tabular}{ccc}
\hline No & Komposisi Bahan Baku & Nilai Rata-rata \\
\hline 1 & 100 gram & 2,73 \\
2 & 200 gram & 2,46 \\
3 & 300 gram & 3,87
\end{tabular}

Keterangan skala penilaian $1=$ Suka sekali $: 2=$ Suka $: 3=$ Agak suka $: 4=$ Tidak suka $: 5=$ Sangat tidak suka

Berdasarkan uji organoleptik mutu 200 gram lebih porous, sehingga setelah tekstur diatas penelis/konsumen dikukus atau direbus mie lebih padat dan menyukai mie tepung pisang dengan kenyal, sedangkan mie tepung pisang penambahan 100 gram tepung pisang, dari sampel 100 gram dan 300 gram hal ini alasannya dilihat dari tekstur dari banyak yang putus-putus.

ketiga sampel, mie tepung pisang dengan

Tabel 6. Anova terhadap Mutu Tekstur

\begin{tabular}{llllll}
\hline SV & Db & JK & MS & F Hitung & F Tabel \\
\hline Panelis & 79 & 105,15 & 1,33 & 0,30 & 1,36 \\
Perlakuan & 2 & 89,72 & 44,86 & 10,38 & 3,06 \\
Error & 158 & 682,98 & 4,32 & - & - \\
\hline $\begin{array}{l}\text { F Hitung > Tabel Berberda Nyata } \\
\text { F Hitung < Tabel Tidak Berbeda Nyata }\end{array}$ & & &
\end{tabular}

Berdasarkan uji sensoris yang dilakukan berdasarkan parameter tekstur nilai, berati tidak berbeda nyata, hal ini menyatakan bahwa penilaian panelis terhadap parameter tekstur tidak berbeda nyata, karena pengamatan panelis antara ketiga sampel tidak berbeda nyata artinya hampir sama, sedangkan pada masing- masing perlakuan menunjukan hasil yang berbeda nyata.

\section{SIMPULAN}

Hasil penelitian dapat diambil kesimpulan berdasarkan parameter warna, panelis konsumen lebih menyukai mie tepung pisang dengan penambahan 
200 gram tepung pisang dengan nilai rata-rata 2,50 yang berada pada skala suka. Berdasarkan atribut mutu rasa, panelis konsumen lebih menyukai mie tepung pisang dengan penambahan 200 gram tepung pisang dengan nilai rata-rata 2,48 yang berada pada skala suka. Berdasarkan atribut mutu tekstur, panelis konsumen lebih menyukai mie tepung pisang dengan 200 gram mie tepung pisang dengan nilai rata-rata 2,46 yang berada pada skala suka.

DAFTAR PUSTAKA
Almatsier S. 2009. Prinsip Dasar Ilmu Gizi. Jakarta : Gramedia Pustaka Utama. Jakarta

Cinthya, 2006. Teknologi Budidaya Tanaman Pisang, Bina Aksara, Jakarta

Kartasapoetra, A.G.1998. Teknologi Budidaya Tanaman Pangan di Daerah Tropik. Bina Angkasa. Jakarta

Sufi, 2009. Pangan dan Gizi. penerbit Dian Rakyat. Jakarta

Soekarto,S.T, 1985. Penilaian Industri Pangan dan Hasil Pertanian. Bina Angkasa. Jakarta

Winarno, F.G. 1995. Kimai Pangan dan Gizi. Gramedia Pustaka Utama. Jakarta 